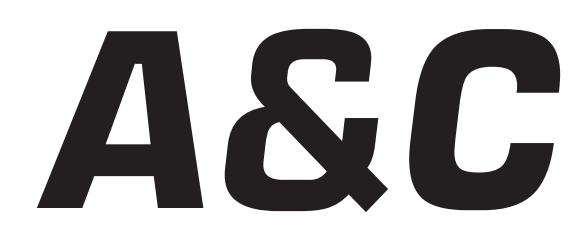

Revista de Direito Administrativo \& Constitucional

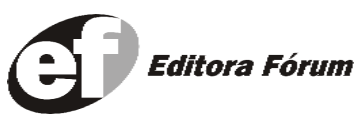

A\&C R. de Dir. Administrativo e Constitucional, Belo Horizonte, ano 5, n.19, p. 1-254, jan./mar. 2005 


\section{A\&C REVISTA DE DIREITO ADMINISTRATIVO E CONSTITUCIONAL}

\section{IPDA}

Instituto Paranaense

de Direito Administrativo

Direção Geral

Romeu Felipe Bacellar Filho

Direção Editorial

Paulo Roberto Ferreira Motta

Direção Executiva

Emerson Gabardo

Conselho de Redação

Edgar Chiuratto Guimarães

Adriana da Costa Ricardo Schier

Célio Heitor Guimarães

Conselho Editorial

Adilson Abreu Dallari

Alice Gonzáles Borges

Carlos Ari Sundfeld

Carlos Ayres Britto

Carlos Delpiazzo

Cármen Lúcia Antunes Rocha

Celso Antônio Bandeira de Mello

Clèmerson Merlin Clève

Clóvis Beznos

Enrique Silva Cimma

Eros Roberto Grau

Fabrício Motta

Guilhermo Andrés Muñoz (in memoriam)

Jaime Rodríguez-Arana Muñoz

Jorge Luís Salomoni
José Carlos Abraão
José Eduardo Martins Cardoso

José Luís Said

José Mario Serrate Paz

Juan Pablo Cajarville Peruffo

Juarez Freitas

Julio Rodolfo Comadira

Luís Enrique Chase Plate

Lúcia Valle Figueiredo

Manoel de Oliveira Franco Sobrinho

(in memoriam)

Marçal Justen Filho

Marcelo Figueiredo

Márcio Cammarosano

Maria Cristina Cesar de Oliveira
Nelson Figueiredo

Odilon Borges Junior

Pascual Caiella

Paulo Eduardo Garrido Modesto

Paulo Henrique Blasi

Paulo Neves de Carvalho (in memoriam)

Paulo Ricardo Schier

Pedro Paulo de Almeida Dutra

Regina Maria Macedo Nery Ferrari

Rogério Gesta Leal

Rolando Pantoja Bauzá

Sérgio Ferraz

Valmir Pontes Filho

Yara Stropa

Weida Zancaner

\footnotetext{
A246 A\&C Revista de Direito Administrativo e Constitucional. ano 3, n. 11, jan./mar. 2003. Belo Horizonte: Fórum, 2003.

Trimestral

ano 1, n.1, 1999 até ano 2, n.10, 2002 publicada pela Editora Juruá em Curitiba

ISSN: 1516-3210

1. Direito Administrativo. 2. Direito Constitucional. I. Fórum.
}

CDD: 342 CDU: 33.342

(c) Editora Fórum Ltda. 2005

Todos os direitos reservados. É proibida a reprodução total ou parcial, de qualquer forma ou por qualquer meio eletrônico ou mecânico, inclusive através de processos xerográficos, de fotocópias ou de gravação, sem permissão por escrito do possuidor dos direitos de cópias (Lei $n^{\circ}$ 9.610, de 19.02.1998).

Editora Fórum Ltda

Av. Afonso Pena, 2770 - 15\%16ªndar - Funcionários

CEP 30130-007 - Belo Horizonte/MG - Brasil

Tel.: 08007043737

Internet: www.editoraforum.com.br

e-mail: editoraforum@editoraforum.com.br
Editor responsável: Luís Cláudio Rodrigues Ferreira Projeto gráfico e diagramação: Luis Alberto Pimenta Revisora: Olga M. A. Sousa

Pesquisa jurídica: Fátima Ribeiro - OAB/MG 74868

Bibliotecária: Nilcéia Lage de Medeiros

CRB 1545/MG 6a região

Os conceitos e opiniões expressas nos trabalhos assinados são de responsabilidade exclusiva de seus autores.

Impressa no Brasil / Printed in Brazil

Distribuída em todo Território Nacional 


\title{
Fenômeno Convencional, Sistema Brasileiro de Recepção de Tratados Internacionais e a Necessidade Hodierna de Integração Econômica
}

Melina Breckenfeld Reck

Advogada militante, sócia da Clèmerson Merlin Clève Advogados Associados. Mestre em Direito do Estado pela UFPR. Professora de Direito Econômico e Assessora Jurídica da UniBrasil

\begin{abstract}
Sumário: Introdução - I Intensificação do fenômeno convencional: estreita relação entre tratado internacional e organizações internacionais - II Celebração e recepção no direito interno dos tratados internacionais e responsabilização internacional - III As clássicas concepções: monismo e dualismo - IV A recepção e a hierarquia dos tratados internacionais no Direito brasileiro - V Fragilidade da regra brasileira de recepção de tratados internacionais e integração econômica - Conclusão - Bibliografia
\end{abstract}

\section{Introdução}

O escopo precípuo da presente análise consiste em tratar sobre a relação entre o fenômeno convencional, o sistema brasileiro de incorporação/ recepção de tratados internacionais e a necessidade hodierna de integração econômica, a fim de avaliar se a positivação conferida a tal incorporação constitui ou não óbice à efetivação da integração de um modo geral.

Para tanto, dividir-se-á o estudo em cinco grandes partes.

Na primeira, abordar-se-á a intensificação do fenômeno convencional, mediante um aumento na celebração de tratados internacionais, e sua estreita relação com o surgimento e fortalecimento das organizações internacionais.

Na segunda, realizar-se-á uma contraposição entre a recepção dos tratados internacionais pelo direito interno e a inafastável responsabilidade internacional dos Estados que celebram tais pactos, destacando-se o fato de o ordenamento nacional não constituir razão que justifique o descumprimento de compromissos internacionais, tampouco impedir a sujeição à responsabilidade internacional.

O tema geral da recepção/incorporação também está presente nas partes terceira e quarta, na medida em que se analisarão, respectivamente, as concepções clássicas - monismo e dualismo - e a recepção e a hierarquia dos tratados internacionais no direito brasileiro. 
Por fim, na última parte, explanar-se-á, de modo geral, sobre os efeitos que a fragilidade da regra brasileira enseja em relação à necessidade de integração, bem como a inexistência de antinomia entre integração e soberania; ressalve-se, por oportuno, que essa abordagem não incluirá, em que pese a extrema relevância, considerações específicas sobre os fenômenos da União Européia e Mercosul, uma vez que tal análise importaria, por força, aliás, de sua complexidade, um estudo que ultrapassaria o escopo precípuo acima delineado.

\section{Intensificação do fenômeno convencional: estreita relação entre tratado internacional e organizações internacionais}

Desde o período antigo, os Estados visam, através de tratados e pactos, a estabelecer e manter a paz, todavia, somente em meados do século XIX, ${ }^{1}$ o fenômeno convencional foi impulsionado e sofreu uma transformação considerável, em virtude da crescente solidariedade ${ }^{2}$ entre os diversos elementos da sociedade internacional.

Segundo Paul Reuter, essas solidariedades, inicialmente, externam-se dentro dos Estados, sendo o tratado internacional uma forma de transcender o âmbito interno, ainda que se mantenha o esteio nas instituições nacionais que são imprescindíveis à celebração e execução dos tratados. Demais disso, o surgimento do tratado multilateral é um inequívoco sintoma da transformação do fenômeno convencional, mesmo porque tal espécie de tratado permitiu não só substituir vários contratos bilaterais por um instrumento multilateral, embora este não seja uma mera soma daqueles, mas também a proteção a interesses comuns da humanidade, mesmo porque, nos tratados multilaterais, prevalece a combinação de esforços para lograr um objetivo comum e não uma mera justaposição de compromissos relativos a interesses divergentes.

Por outro lado, não se olvide que há estreita relação entre a intensificação desses instrumentos e o surgimento das organizações

\footnotetext{
1 Cfr. REUTER, Paul. Introdución al Derecho de los Tratados. Ed. Revisada por Peter Haggenmacher. Cidade do México: Fondo de Cultura Económica, 1999. Reuter, nessa obra, explana, dentre outros assuntos, acerca da evolução histórica do fenômeno convencional, através da estruturação de três grandes períodos: de 1815

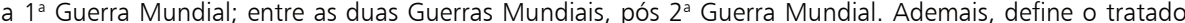
como uma manifestação de vontades concordantes, imputáveis a dois ou mais sujeitos de direito internacional e destinada a produzir efeitos jurídicos conforme as normas de Direito Internacional. É necessária a manifestação, isto é, que sejam externadas as vontades.

2 Solidariedade essa tão importante entre Estados que qualquer mudança de seus elementos implica a alteração do equilíbrio do poder dentro da totalidade do sistema, bem como exige que os problemas na sociedade internacional sejam resolvidos de forma comunitária e simultânea.
} 
internacionais, uma vez que, os conclaves, cujos produtos finais são os tratados multilaterais, têm apresentado caráter periódico, de modo a se criarem órgãos e secretarias permanentes que usufruem de autonomia jurídica diante dos Estados participantes. De tal sorte, surgem as organizações internacionais que têm, por sua vez, nos tratados, seus atos constitutivos, e que implicam, aliás, uma grande expansão do movimento convencional, na medida em que não só promovem um maior número de tratados multilaterais entre si ou com Estados, mas também propõem novas soluções em relação à forma e à execução adequada dos tratados.

Embora haja ainda muita discussão teórica acerca da definição das fontes do direito internacional, ${ }^{3}$ por força do disposto no artigo $38^{4}$ do Estatuto da Corte Internacional de Justiça que estabelece os instrumentos de solução de controvérsias, os tratados, ao lado do costume e dos princípios gerais de direito, constituem as fontes primárias do Direito Internacional Público, na medida que tal dispositivo considera a jurisprudência e a doutrina meios auxiliares cuja função estaria limitada à equidade.

Como se vê, os tratados multilaterais e as organizações internacionais devem ser considerados as principais causas da evolução do fenômeno convencional $^{5}$ e constituem resultado da crescente solidariedade internacional, embora não seja irrelevante a prática internacional, através dos serviços protocolares e jurídicos nacionais e internacionais que são submetidos a fortes pressões da solidariedade nacional no sentido de propor soluções mais econômicas e realistas.

No bojo dessa evolução do fenômeno convencional e "com a importância crescente do tratado no rol das fontes do Direito Internacional Público, o conflito eventual entre este e o direito interno passou a ser enfocado primordialmente sob a ótica da integração do ato convencional à ordem jurídica nacional". ${ }^{6}$

\footnotetext{
3 TRINDADE, Antônio Cançado. O Direito Internacional em um Mundo em Transformação. Rio de Janeiro: Renovar, 2002, p. 19.

4 Projeto desse artigo foi redigido pelo Barão Descamps e discutido por Mr. Root e Lord Phillimore.

5 A ONU foi responsável pela codificação do direito dos tratados. Nesse aspecto, a Convenção de Viena de 1969 teve um alcance muito grande, embora não tenha esgotado as questões relativas aos tratados de modo a ter sido seguida pela de agosto de 78 e de março de 1986, sendo que nesta cuidou dos tratados entre organizações internacionais e entre essas e os Estados. Há, portanto, o emergir de um direito dos tratados preciso e desenvolvido, os quais, em virtude de suas relações com as organizações, tendem a tornar-se permanentes; bem como há a tendência de se conferir às organizações a possibilidade de supervisionar a entrada em vigor dos tratados. (Cfr. REUTER, op. cit., p. 28)

6 DALLARI, Pedro B. A Constituição e Tratados Internacionais. São Paulo: Saraiva, 2003, p. 18-19.
} 


\section{Celebração e recepção no direito interno dos tratados internacionais e responsabilização internacional}

A recepção dos tratados internacionais na ordem jurídica interna dos Estados partes, embora seja tema clássico da teoria do Direito Internacional Público, ainda é motivo de acirrada discussão em situações concretas, ${ }^{7}$ principalmente quando se trata da definição da implicação/repercussão dos tratados nos ordenamentos nacionais.

Há diferentes modelos constitucionais de sistemas de integração dos Tratados ao Direito Interno. Segundo Mirtô Fraga, existiriam quatro espécies: (i) adoção global da regra do Direito Internacional pelo direito interno, sem, todavia, instituir a primazia de uma sobre a outra; (ii) adoção global com primazia do direito internacional; (iii) sistema de incorporação obrigatória, mas não automática; (iv) aqueles cuja Constituição, embora submeta o Estado ao direito internacional, não trata da integração deste no direito interno. ${ }^{8}$

No rol dos Estados, cujas Constituições são silentes no tocante à recepção dos tratados, é possível relacionar, no período por volta de 1985, os países do denominado 'bloco socialista', com exceção da URSS, países do terceiro mundo e até mesmo países desenvolvidos do bloco ocidental, como a Itália e a República Federal da Alemanha, se bem que, em relação a este último, como se verá mais à frente, pode-se considerar implícita, pelo contexto em que está situada, a referência aos tratados na formulação 'normas gerais de Direito Internacional Público.."9

De outra parte, a Constituição dos EUA foi apresentada por Cassese como exemplo maior dos sistemas da segunda categoria, aqueles que, fazendo alusão à necessária observância dos tratados internacionais, não lhes conferem posição superior à legislação do Estado. No entanto, ressalvese que por se tratar de uma federação, os tratados não podem ser desconsiderados pelas Constituições e leis dos Estados que integram a União, mas podem ser superados pela legislação federal.

Como exemplo de países que adotam sistemas que conferem aos tratados o status de 'quasi-constitutional law', em 1985, é possível citar o Japão, a Espanha, a França, as antigas colônias francesas e alguns países 7 Cf. DALLARI, op. cit., p. XI. O tema da recepção dos tratados internacionais, para Pedro Dallari, compreende duas dimensões distintas, quais sejam: a recepção do Direito Internacional Público no direito interno e a da recepção dos tratados internacionais pelo sistema de normas de direito positivo do Estado. (ibid, p. 7)

8 FRAGA, Mirtô. O Conflito entre Tratado Internacional e Norma de Direito Interno: Estudo Analítico da Situação do Tratado na Ordem Jurídica Brasileira. Rio de Janeiro: Forense, 1997, p. 15.

9 CASSESE, Antonio. Modern Constitutions and Internacional Law. Recueil des Cours de l'Académie de Droit International de la Haye, 1985 III, Tomo 192, Dordrecht (Holanda): Martinus Nijhoff Publishrs, 1986, p. 394.

A \& C R. de Dir. Administrativo e Constitucional, Belo Horizonte, ano 5, n. 19, p. 127-159, jan./mar. 2005 
latino-americanos — Costa Rica (Constituição de 1949), Paraguai (1967) e Peru (1979).

Por fim, a Holanda e uma sua antiga colônia, o Suriname, são os únicos casos em que se adotou, na época de 1985, sistemas que admitem a capacidade de os tratados derrogarem inclusive disposição de natureza constitucional. Pedro Dallari relativiza um pouco esse exemplo, destacando que, "ao se examinar o caso holandês, na verdade a presunção da materialização de uma hipótese de derrogação de texto da Constituição parece pouco consistente, na medida em que se constata que, na verdade, o que o sistema constitucional daquele país prevê é a possibilidade de adoção simultânea, com o quorum adotada para a reforma da Constituição, de um tratado e de uma emenda constitucional voltada à superação do eventual obstáculo à incorporação da norma convencional internacional." ${ }^{10}$

Como se vê, a diferença existente entre esses modelos, mesmo com a adaptação aos tempos hodiernos, denota a dificuldade que efetivamente é imposta à plena observância dos tratados no âmbito do sistema jurídico de cada Estado, não obstante a crescente propensão à pactuação na esfera do Direito Internacional Público. ${ }^{11}$

No entanto, a avaliação desses modelos urge ser atualizada, pois o tratamento conferido ao tema da recepção/integração dos tratados nos sistemas constitucionais foi alterado sensivelmente desde 1985 quando foi feita a análise de Antonio Cassese, mesmo porque sucederam acontecimentos de enorme impacto na ordem internacional. Está-se a referir à “intensificação de processos de integração internacional, e, no mundo ocidental, esse incremente se materializou, inclusive, em reformas dos sistemas constitucionais estatais, que passaram a contemplar mais objetivamente a disciplina jurídica da recepção e integração dos tratados." 12

Por outro lado, ainda em relação ao tema desse tópico, conforme entendimento de Paul Reuter, em regra, parte das normas que regem a celebração dos tratados são estabelecidas pelas constituições nacionais ${ }^{13}$ e o restante pelo direito consuetudinário que restou completado pela Convenção de Viena de 1969; ao passo que a aplicação dos tratados é regulada principalmente pelo direito internacional, embora em alguns ${ }^{10}$ DALLARI, op. cit., p. 23.

${ }^{11}$ Cf. DALLARI, op. cit. p. 23.

12 Ibid., p. 24.

${ }_{13}$ Para Eduardo Aréchaga, "tampoco la questión de cuál norma prevalece en caso de conflicto entre las reglas de Derecho Internacional y las de Derecho Interno, es regida por el Derecho Internacional sino que depende del Derecho Constitucional de cada Estado." ("La Convención...., p. 27-28 apud DALLARI, op. cit., p. 124-125)

A \& C R. de Dir. Administrativo e Constitucional, Belo Horizonte, ano 5, n. 19, p. 127-159, jan./mar. 2005 
casos dependa do direito interno tal como na unificação do regime jurídico do cheque.

De fato, Paul Reuter, após definir os tratados como manifestações de vontades concordantes de dois ou mais sujeitos de direito internacional, ressalta que o processo de atribuição de uma vontade é regido em cada país pelo direito internacional, o qual, todavia, geralmente, refere-se ao ordenamento jurídico de cada Estado.

Como se vê, há uma imbricação entre dois ordenamentos jurídicos distintos, havendo quase sempre a indagação relativa a qual seria o ordenamento aplicável. Indagação essa analisada por diversas teorias abstratas, umas monistas e outras dualistas. ${ }^{14}$

Em que pese essa imbricação, não se olvide que o cumprimento das normas internacionais postas por tratados é assegurado pela responsabilidade internacional. De tal sorte, "pouco importa para o direito das gentes a divisão interna, constante na Constituição, sobre competências e incorporação. O que é da importância capital para direito internacional é que as obrigações assumidas pelo Estado sejam cumpridas, seja lá como for o processo interno de decisão constante na Constituição do Estado; a infração dos deveres assumidos enseja a responsabilização do Estado perante o direito internacional público. E tal responsabilidade internacional é imposta ao Estado como resultado de decisões dadas no âmbito de seu Legislativo, seu Executivo ou seu Judiciário." ${ }^{15}$

Independentemente do que prevêem os ordenamentos internos, não se pode olvidar do fato de que, para as instituições genuinamente internacionais, e a regra geral é que o descumprimento do pacto internacional implica, conforme a interpretação de dispositivos constantes na Convenção de Havana sobre Tratados (ratificada, aliás, pelo Brasil), na Convenção de Viena sobre o Direito dos Tratados e da Corte Permanente de Justiça, ao Estado faltoso a responsabilização internacional. ${ }^{16}$

Como se vê, o direito interno do Estado-parte não constitui pretexto,

\footnotetext{
14 Teorias que serão adiante analisadas.

15 PAGLIARINI, Alexandre Coutinho. Constituição e Direito Internacional: Cedências Possíveis no Brasil e no Mundo Globalizado. Rio de Janeiro: Forense, 2003, p. 152. Em outro excerto, ressalta esse autor: "O direito internacional é indiferente ao método eleito pelo Estado para promover a recepção da norma convencional por seu ordenamento jurídico. Importa-Ihe tão-só que o tratado seja de boa-fé, cumprido pelas partes. Nos Países Baixos, entre 1906 e 1953, ignorava-se conscientemente qualquer prática expressiva do fenômeno da recepção; atitude que, ao gosto dos pensadores monistas, retratava a operatividade da norma internacional por sua própria e originária virtude, com o permeio de qualquer diploma interno de incorporação." (Ibid., p. 149)

${ }^{16}$ Em 31/07/1939, a Corte Internacional de Justiça pronunciou-se no seguinte sentido: "É princípio geral reconhecido, do direito internacional, que, nas relações entre potências contratantes de um tratado, as
} 
tampouco justificativa plausível, no âmbito do Direito Internacional Público, ao descumprimento de um tratado internacional, cuja aquiescência de tal Estado ao pacto tenha sido livremente externada como inequívoca manifestação de vontade. Logo, deve o Estado que não pretende cumprir determinada norma internacional recorrer à renúncia desse tratado, não lhe sendo possível, para tanto, esteiar-se no direito interno.

Destarte, como bem ressalta Paul Reuter, quanto à aplicação dos pactos, os tratados e convenções são celebrados para serem executados, daí a necessidade de serem aplicados pelos tribunais nacionais, principalmente quando estipulam direitos e obrigações aos indivíduos. Geralmente, a aplicação das normas estabelecidas por tratados exige a implantação prévia de medidas reguladoras, administrativas ou financeiras, que são imprescindíves à execução do acordo. Prevalecendo, nessa seara, o princípio básico de direito internacional que confere a possibilidade do direito constitucional de cada Estado solucionar os problemas derivados da aplicação, pelos tribunais nacionais, de normas de direito internacional, sem, todavia, olvidar-se que o Estado não pode invocar disposições de seu direito interno a fim de justificar o descumprimento de um tratado, apenas lhe é facultada a possibilidade de eleger os meios de execução que repute convenientes, conforme suas tradições e princípios fundamentais de sua organização política, sob pena de ser responsabilizado internacionalmente.

Em suma, o tratado vincula os Estados, porque esses aquiesceram em vincular-se a ele.

\section{As clássicas concepções: monismo e dualismo}

A relação e equacionamento entre Direito Internacional Público e o direito interno, segundo Pedro Dallari, ${ }^{17}$ foram objeto de duas clássicas concepções: monista e dualista. Isto é, ou os dois ordenamentos jurídicos são independentes, distintos, separados e impenetráveis (dualismo) ou derivam um do outro (monismo).

No entanto, essas concepções clássicas têm sido objeto de críticas que ora destacam uma espécie de impertinência da dicotomia; ora vislumbram, na situação atual das relações internacionais, uma posição intermediária, não isenta, todavia, de variações conforme os grupos de Estados interessados;

\footnotetext{
disposições de uma lei não podem prevalecer sobre as do tratado". (ACCIOLY, Hildebrando. Manual de Direito Internacional Público, 1978, p. 6)

17 DALLARI, op. cit., p. 8.
}

A \& C R. de Dir. Administrativo e Constitucional, Belo Horizonte, ano 5, n. 19, p. 127-159, jan./mar. 2005 
ora que, por conta do movimento de integração, haveria um trialismo. ${ }^{18}$

Em que pese tais críticas a essas concepções clássicas, explanar-se-á a seguir um pouco sobre elas.

Pois bem, Paul Reuter, ${ }^{19}$ em rápida síntese, leciona que os dualistas entendem que o direito internacional e o nacional são absolutamente distintos, salvo para o Chefe de Estado a quem cabe representar o Estado em ambas as searas. Ao passo que os monistas preconizam que o direito nacional permaneceria ligado e submetido ao direito internacional com relação a todos os órgãos estatais.

Paul Reuter ressalta, ainda, que a definição da teoria adequada varia conforme o país interessado e as condições históricas. ${ }^{20}$ Por exemplo, o monismo encontra aplicação nos casos em que a integração jurídica equivale a uma integração social completa, isto é, quando a sociedade internacional é suficientemente forte para convergir e harmonizar as estruturas e as relações sociais de menor amplitude. No entanto, quando não há sociedade internacional e os Estados permanecem hermeticamente fechados ao mundo exterior, prevaleceria o dualismo, o qual reflete a idéia de um Estado que rechaça a integração jurídica, uma vez que não há uma integração social nem a intenção de estabelecê-la.

Por conta dessas variações, emergiria, ainda segundo Reuter, ${ }^{21}$ um problema prático relativo à interpretação uniforme dos convênios multilaterais pelos vários tribunais nacionais, a fim de evitar que a unidade convencional desmorone pela diversidade de interpretações jurisprudenciais nacionais. Soluções propostas seriam no sentido de haver uma instância recursal internacional ou de impor aos tribunais nacionais a obrigação, como ocorre na Comunidade Européia, de submeter os problemas de interpretação e de validade de certas decisões unilaterais a um tribunal internacional mediante questões de prévio e especial pronunciamento. A solução mais radical e distante de ser adotada seria assegurar a supremacia do direito internacional sobre o nacional, inclusive quando este for posterior àquele.

\footnotetext{
18 STRAUS, Flávio Augusto Saraiva. Soberania e Integração Latino-Americana - Uma perspectiva Constitucional do Mercosul. Rio de Janeiro: Forense, 2002, p. 54.

${ }^{19}$ REUTER, op.cit., p. 32.

${ }^{20} \mathrm{Id}$. Em um Estado estritamente dualista, os tribunais somente poderão aplicar uma norma convencional se já estiver transformada em direito nacional, mediante, em regra, um ato legislativo. Em outros Estados, os tribunais aplicam o Direito Internacional sem recorrer a nenhuma transformação prévia em direito nacional, bem como a norma internacional seria hierarquicamente superior à legislação nacional.

${ }^{21}$ REUTER, op. cit., p. 32
}

A \& C R. de Dir. Administrativo e Constitucional, Belo Horizonte, ano 5, n. 19, p. 127-159, jan./mar. 2005 
Detecta-se outra dificuldade, ao se cotejar o Direito e a comunidade internacional com um Estado Federal, na medida em que, enquanto em um Estado Federal, as relações entre o direito federal e direito estatal nos tribunais dos Estados que integram a federação são regidas pelo direito desta última; na comunidade internacional, ocorre o inverso, uma vez que as relações entre direito internacional e direito nacional nos tribunais nacionais são regidas pelo direito nacional.

Diante dessa problemática, é pertinente lembrar o magistério de Pedro Dallari, segundo o qual haveria uma necessidade preemente de "compatibilização dos paradigmas fundamentais de Direito Internacional Público relacionados aos tratados com aqueles, próprios do Direito Constitucional, referentes à incidência dos princípios de processo legislativo na configuração da estrutura hierárquica das normas jurídicas". ${ }^{22}$

Pois bem, Kelsen, ao sistematizar essas duas concepções, ressaltou que a concepção dualista pressupõe a total separação entre as instituições e fontes jurídicas do Direito Internacional Público e do direito interno, de modo que a validade de um norma aplicável internamente depende exclusivamente de atos próprios da atividade legislativa do Estado, não interferindo para essa validade a compatibilidade dessa norma com os compromissos formais e políticos assumidos por esse Estado para com a ordem jurídica internacional. ${ }^{23}$ Essa tese dualista foi defendida principalmente por Triepel, ${ }^{24}$, na Alemanha, e Anzilotti, na Itália. ${ }^{25}$

Para Dallari, o dualismo refletiria um Direito Internacional Público em que predominavam normas de natureza eminentemente contratual, fixadoras de regras políticas de convivência entre Estados soberanos. No século XX, paulatinamente, começaram a emergir os tratados de natureza marcadamente normativa, relativos à adoção de regras jurídicas uniformizadoras de padrões de conduta vinculando indivíduos e pessoas jurídicas de direito privado subordinados à soberania dos respectivos Estados contratantes no plano internacional. Sob o viés dualista, haveria a recepção do

\footnotetext{
22 DALLARI, op. cit., p. XVI.

${ }^{23}$ KELSEN, Hans. Les Rapports de Système entre le Droit Interne et el Droit International Public. Recueil des Cours de l'Académie de Droit International de la Haye, 1926, IV. Paris (França): Librairie Hachette, 1927, p. 231-331.

${ }^{24} \mathrm{O}$ tema do conflito entre as normas internacionais e o ordenamento interno importa na análise de duas grandes concepções doutrinárias, quais sejam: "o dualismo, pregado no âmbito internacional por Triepel e Anzilotti e seguido no Brasil por Amílcar de Castro, e o monismo, concepção desenvolvida por Hans Kelsen e seguida no Brasil pela maior parte da doutrina, inclusive Valladão, Tenório, Celso D. de Albuquerque Mello e Marotta Rangel." (BARROSO, L.R. Interpretação e Aplicação da Constituição. 4. ed. São Paulo: Saraiva, 2001, p. 15)

${ }^{25}$ Cf. DALLARI, op. cit., p. 8-9.
}

A \& C R. de Dir. Administrativo e Constitucional, Belo Horizonte, ano 5, n. 19, p. 127-159, jan./mar. 2005 
Direito Internacional Público pelo direito interno, mas não a integração entre os dois sistemas normativos, uma vez que do Direito Internacional Público, ao qual estaria adstrito o Estado, apenas emanariam diretrizes de jaez política direcionadas às instituições responsáveis pela produção das normas de direito interno. De outra parte, na essência da concepção monista encontra-se a plena integração do direito interno com o Direito Internacional, até porque a própria teoria expressamente sinaliza no sentido da unidade de ambas as ordens jurídicas. ${ }^{26}$

Deveras, "a doutrina, Kelsen inclusive, identificou na unidade do direito público preconizada pelo monismo (...) a emergência de duas ramificações, derivadas da primazia do Direito Internacional Público em relação ao direito interno ou vice-versa. A prevalência do Direito Internacional Público caracteriza o monismo internacionalista. Já o monismo nacionalista resulta do contrário, ou seja, da subordinação, mesmo que em um quadro de unidade, do Direito Internacional Público ao direito interno." ${ }^{27}$

No mesmo sentido, Hildebrando Accioly preconiza que o direito é um só, quer se apresente nas relações de um Estado, quer nas relações internacionais, havendo "duas esferas de ação: uma interna e a outra externa; a primeira, regulada, em cada Estado, pelo respectivo direito interno; a segunda, regida pelo direito internacional". ${ }^{28}$

Destarte, segundo os dualistas, não haveria possibilidade de conflito entre a ordem internacional e o ordenamento interno uma vez que não existiria interseção entre ambas. Tratar-se-ia de esferas distintas, que não se tocam. É dizer, as normas de direito internacional disciplinam as relações entre Estados, e entre estes e os demais integrantes da sociedade internacional, ao passo que o direito interno regeria as relações intra-estatais, sem qualquer conexão com elementos externos. De tal sorte, um ato internacional, como tratado normativa, apenas surtirá efeitos no âmbito interno de um Estado se uma lei vier incorporá-lo ao ordenamento jurídico positivo. De outro lado, propugna o monismo jurídico que o direito constitui uma unidade, um sistema integrado não só pelo direito interno, mas também pelo direito internacional, logo são necessárias normas que coordenem esses dois domínios e que determinem qual deles deve prevalecer em caso de conflito. Neste particular, Kelsen, embora perfilhe a tese de prevalência

\footnotetext{
${ }^{26}$ Ibid, p. 9

${ }^{27}$ DALLARI, op. cit., p. 10.

${ }^{28}$ ACCIOLY, Hildebrando. Manual de Direito Internacional Público. 12. ed. São Paulo: Saraiva, 1996.
}

A \& C R. de Dir. Administrativo e Constitucional, Belo Horizonte, ano 5, n. 19, p. 127-159, jan./mar. 2005 
do direito internacional, também admite a existência da tese de prevalência do direito interno. ${ }^{29}$

Alexandre Pagliarini, a propósito da relação entre direito interno e o direito internacional, confere duas possibilidades ao jurista:

Efetivamente, tudo depende do ponto de vista do cientista do direito: ou ele guarda a posição firme - constitucionalista - de que é a Constituição que determina a hierarquia existente entre normas internacionais e normas internas; ou é defensor de uma visão - internacionalista radical — que faz com que se entenda que a norma pactícia se sobrepõe à doméstica e adentra nos ordenamentos locais, independentemente de serem vertidas em normas nacionais. Tal posição internacionalista, como é de se esperar, foi a defendida - como visto - pela Convenção de Havana sobre Tratados, pela Convenção de Viena sobre o Direito dos Tratados e pela Corte Permanente de Justiça Internacional. ${ }^{30}$

Em excelente estudo de direito comparado, Luiz Roberto Barroso assevera:

A Constituição da maior parte dos países europeus contém regras sobre as relações entre o direito interno e o direito internacional, normalmente no sentido de considerar este último como parte integrante do primeiro. Não, assim, a Constituição da França, de 1958, que é expressa no sentido da superioridade do direito internacional, bem como a da Holanda, de 1983. A verdade, no entanto, é que a jurisprudência restritiva dos tribunais tende a neutralizar essa supremacia formal, salvo quanto ao direito comunitário europeu, que tem desfrutado de primazia sobre o direito interno.

Nos Estados Unidos, a jurisprudência, de longa data, considerou os tratados e convenções internacionais incorporados ao direito interno, na interpretação dada ao art. $6^{\circ}, 2^{\mathrm{a}}$ seção, da Constituição. Aos atos internacionais adequadamente aprovados pelo Congresso reconhece-se o mesmo nível das leis federais, de forma tal que o posterior prevalece sobre o anterior. Paradoxalmente, na prática, o direito internacional é freqüentemente privilegiado, por força de uma atitude de deferência dos tribunais americanos, que somente consideram derrogados os atos internacionais quando seja evidente a intenção do Legislativo nesse sentido. ${ }^{31}$

Alexandre Pagliarini, por sua vez, acentua:

Não se verifica nenhuma fronteira intransponível entre direito interno e direito internacional. No direito nacional, há centralização suficiente para que o mesmo possa ser considerado como um sistema de normas válidas, dispostas escalonadamente num contexto hierarquizado. A mesma interferência definitivamente não vale para o direito das gentes, pois é descentralizado, tendo Kelsen o

\footnotetext{
${ }^{29}$ BARROSO, Luís Roberto, op. cit., p. 16.

30 PAGLIARINI, op. cit., p. 143.

${ }^{31}$ BARROSO, op. cit., p. 17
}

A \& C R. de Dir. Administrativo e Constitucional, Belo Horizonte, ano 5, n. 19, p. 127-159, jan./mar. 2005 
comparado ao direito interno dos primórdios.

Defender uma tese dualista, que não vislumbre qualquer interseção entre o ordenamento jurídico interno e internacional, implica em desconsiderar o direito como objeto que deva ser visto sob o prisma sistemático. Por isso, o monismo explica melhor a convivência dos dois ordenamentos. E, realmente, com muita freqüência se torna difícil separar o direito nacional do internacional, a não ser quando o assunto for, única e exclusivamente, a identificação da fonte positivadora. ${ }^{32}$

Charles Rousseau observa que, desde logo, convém ressaltar que as soluções possíveis a esses conflitos encontram-se condicionadas pela posição que se adote acerca do fundamento do direito das gentes. Isto é, a concepção voluntária, segundo a qual o direito internacional repousa sobre o consentimento dos Estados, conduz ao dualismo, ao passo que a concepção objetiva, a qual busca a origem do ordenamento jurídico fora da vontade humana, implica adesão ao monismo. ${ }^{33}$

A propósito do posicionamento de Rousseau, Pedro Dallari ressalta que se deve conferir menor rigidez à posição de que o aspecto contratual do Direito Internacional Público redundaria necessariamente em uma opção dualista. Isso porque somente é concebível, hoje, uma fórmula de disciplina da relação entre as ordens jurídicas interna e internacional que contemple não só o aspecto contratual inerente ao convívio de soberanias, mas também o impacto extremamente relevante provocado pelo desenvolvimento de paradigmas, mormente os concernentes ao Direito Internacional dos Direitos Humanos, aos quais o Estado não pode virar as costas. ${ }^{34}$

Pedro Dallari opta por um monismo de compatibilização que importa na integração das normas de Direito Internacional Público com o direito interno do Estado, bem como "a substituição do enfoque baseado em torno da primazia de uma ou de outra ordem por uma perspectiva de articulação entre ambas, superando-se, assim, a polarização entre monismo internacionalista e monismo nacionalista." ${ }^{35}$

No mesmo sentido, observa Vicente Marotta Rangel que nem a ordem internacional dilui-se na ordem jurídica interna, nem esta naquela se dissolve, vez que elas, ao contrário, condicionam-se e se influenciam

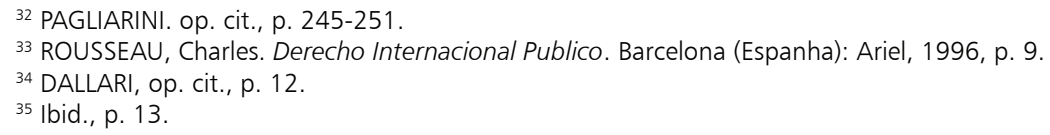

A \& C R. de Dir. Administrativo e Constitucional, Belo Horizonte, ano 5, n. 19, p. 127-159, jan./mar. 2005 
mutuamente. ${ }^{36}$

\section{A recepção e a hierarquia dos tratados internacionais no Direito brasileiro}

Desde logo, transcreva-se excerto de Pedro Dallari "o sistema jurídico brasileiro, de clara vocação monista, como se procurará demonstrar, é carente justamente de normas claras que propiciem a coordenação do Direito Internacional Público com o direito interno e o estabelecimento de regras de prevalência para as hipóteses de conflito." ${ }^{37}$

Aliás, as análises mais recentes sobre a relação entre Direito Internacional Público e direito interno constatam, lamentavelmente, não só a crescente preocupação na análise do processo de vinculação do Brasil a tratados internacionais e incorporação desses ao direito interno, bem como a inexistência de uma regra clara normatizadora dos efeitos dessa incorporação e os prejuízos daí decorrentes. Ausência essa que, conforme se verá adiante, afeta consideravelmente o Mercosul e, por conseguinte, a integração latino-americana. ${ }^{38}$

Deveras, na Constituinte de 1987 e 1988, embora o tema geral da incorporação do Direito Internacional Público no direito interno tenha merecido alguma atenção, o resultado final não contemplou uma positivação adequada para viabilizar uma estrutura normativa coerente e articulada capaz de reger de modo inequívoco o acolhimento dos preceitos emanados dos tratados.

Tal quadro de decepção intensificou-se ainda mais, no exercício do Poder Constituinte de Revisão, uma vez que, não obstante tenha sido objeto de proposta de emenda a fixação de novas diretrizes de integração do Direito Internacional Público ao direito interno, tal projeto não foi aprovado, inexistindo, portanto, inovação no direito positivo que solucionasse os dilemas da recepção dos tratados na ordem jurídica brasileira.

Essa conjuntura verificada na Carta hodierna não foge, todavia, da

\footnotetext{
${ }^{36}$ RANGEL. Vicente Marotta. Os Conflitos entre Direito Interno e os Tratados Internacionais. Revista da Faculdade de Direito da Universidade de São Paulo, São Paulo, ano 62, fasc. 2, 1967.

${ }^{37}$ DALLARI, op. cit., p. 11-12. Em outro excerto, "a atual Constituição do Brasil, de 1988, situa o País justamente no rol dos Estados que não contemplam nas respectivas Cartas normas claras de integração dos tratados internacionais ao direito interno e, muito menos, normas para assimilação de decisões de organizações internacionais. Na classificação de Antonio Cassese anteriormente apresentada, o texto constitucional brasileiro poderia ser enquadrado entre aqueles que, embora contendo alguma referência ao tema da recepção dos tratados, não conferem a esses diplomas normativos internacionais posição hierárquica superior à das regras infraconstitucionais. $E$, dada tal característica, fica reafirmada uma tradição do constitucionalismo nacional e negada, até agora, a adesão a uma tendência crescente no mundo contemporâneo." (DALLARI, op. cit., p. 41)

${ }^{38}$ Cf. DALLARI. op. cit., p. XIII-XIV.
}

A \& C R. de Dir. Administrativo e Constitucional, Belo Horizonte, ano 5, n. 19, p. 127-159, jan./mar. 2005 
tradição constitucional brasileira, eis que, mediante análise da evolução histórica de todas as Cartas, vislumbra-se que elas "foram omissas em relação ao tema da recepção dos tratados internacionais e seus efeitos no direito interno, sendo o tratado, no plano constitucional, enfocado quase que exclusivamente sob a ótica da distribuição de competências entre os poderes, com vistas ao regramento do respectivo processo de celebração e aprovação." ${ }^{9}$

Pois bem, muito embora não haja clareza, precisão, harmonia e exaustão na regra que trata no direito brasileiro da recepção e integração dos tratados internacionais, Dallari sintetiza suas características: (i) a vinculação do Estado brasileiro a um tratado internacional dá-se mediante a sua ratificação ou adesão, a qual resulta de ato do Presidente da República, que deve, por sua vez, ser precedido, em regra, pela aprovação, pelo Congresso Nacional, do texto convencionado; (ii) o tratado passa a produzir efeitos internamente na data para sua entrada em vigência prevista no decreto de promulgação do Presidente da República e após a publicação desse mesmo decreto; (iii) estando em vigor no território nacional, o tratado incorporado resta automaticamente incorporado ao direito brasileiro, sem a necessidade de edição de lei interna que lhe reproduza o teor; (iv) conforme a jurisprudência dominante, o tratado, no plano da hierarquia normativa, equivale à lei interna, aplicando-se os critérios cronológico e da especialidade, bem como não há distinção hierárquica entre diferentes tipos de tratados; (v) o tratado pode ser denunciado pelo Presidente da República, não sendo necessária a autorização prévia do Congresso Nacional; (vi) não há, no direito interno, dispositivo que trate da recepção das decisões emanadas das organizações internacionais. ${ }^{40}$

$\mathrm{O}$ art. 84, VIII, da CF, estabelece que compete, privativamente, ao Presidente da República celebrar tratados, convenções e atos internacionais, sujeitos a referendo do Congresso Nacional. O art. 49, I, por sua vez, dispõe que compete exclusivamente ao Congresso resolver definitivamente sobre tratados, acordos ou atos internacionais que acarretem encargos ou compromissos gravosos ao patrimônio nacional. Em virtude desses dispositivos, para que o Brasil reste vinculado a tratado internacional, devem concorrer atos do Executivo e Legislativo. Àquele cabe determinar, discricionariamente, a iniciativa do processo legislativo de apreciação de tratado no âmbito do Estado brasileiro, através do encaminhamento de mensagem ao

\footnotetext{
39 DALLARI, op. cit., p. 46
}

40 Ibid., p. 86-87.

A \& C R. de Dir. Administrativo e Constitucional, Belo Horizonte, ano 5, n. 19, p. 127-159, jan./mar. 2005 
Congresso Nacional, submetendo à análise dos membros do Legislativo: (i) texto de tratado celebrado pelo chefe do Poder Executivo em nome do país; (ii) texto de tratado multilateral que, mesmo não tendo contado com a participação do Brasil no ato inicial de celebração, deve, a critério do Presidente, merecer apreciação legislativa para eventual adesão; iii) texto de tratado oriundo de organização internacional. Após tal mensagem, a apreciação pelo Congresso é, em regra, etapa essencial e imprescindível à assunção de compromisso do Brasil na ordem jurídica internacional, bem como reflete a exigência democrática de que somente o povo, por meio de sua representação política, tem direito de dispor da soberania nacional pactuando internacionalmente. A aprovação pelo Congresso dá-se através da edição de decreto legislativo, cuja aprovação depende do voto da maioria dos parlamentares presentes nas respectivas sessões deliberativas nas duas Casas (art. 47 da CF), isto é, da maioria simples, igual quorum exigido para aprovar projeto de lei ordinária.

A propósito, Antonio Cachapuz de Medeiros sintetiza esse processo de integração que qualifica de solene e completo, a saber: "pode transcorrer de duas formas: a) inicia com a negociação e a adoção do texto, prossegue com a avaliação interna de suas vantagens e inconvenientes e, no caso de ser aprovado, ocorre a manifestação da vontade do Estado em obrigar-se pelo tratado, o aperfeiçoamente jurídico-internacional dessa vontade e a incorporação do texto do tratado à ordem jurídica interna (negociação assinatura - mensagem ao Congresso Nacional — aprovação parlamentar - ratificação - promulgação); b) o Executivo solicita ao Congresso autorização para aderir a um tratado. Concedida a autorização, é remetido o instrumento de adesão à autoridade depositária do tratado, que leva ao conhecimento das partes a decisão do Brasil de também assumir as obrigações do tratado. Entrando o ato de adesão em vigor no plano internacional, o tratado é incorporado à ordem jurídica interna (mensagem ao Congresso — autorização parlamentar — adesão — promulgação)" ${ }^{41}$

Feitas essas considerações, passemos à análise tanto do cerne do tema da recepção de tratados, qual seja a determinação da sua respectiva posição hierárquica, quanto de alguns julgados do $\mathrm{STF}^{42}$ e do enqua-

\footnotetext{
${ }^{41}$ MEDEIROS, Antonio Paulo Cachapuz de. O Poder de Celebrar Tratados - Competência dos Poderes Constituídos para a Celebração de Tratados, à Luz do Direito Internacional, do Direito Comparado e do Direito Constitucional Brasileiro. Porto Alegre: Sérgio A. Fabris, 1995. p. 458.
} 
dramento do sistema brasileiro.

A esse respeito, Luís Roberto Barroso leciona:

No Brasil não existe disposição constitucional a respeito do tema, o que tem suscitado críticas diversas. Não obstante, no que diz respeito ao conflito entre tratado internacional e norma interna infraconstitucional, a doutrina, como assinalamos pouco atrás, é amplamente majoritária no sentido do monismo jurídico, com primazia para o direito interno, de forma a alterar a lei anterior, mas não pode ser alterado por lei superveniente. Esse entendimento é positivado no art. 98 do Código Tributário Nacional.

Curiosamente, os autores, à unanimidade, vislumbravam essa mesma orientação na jurisprudência constante e reiterada do Supremo Tribunal Federal. Por tal razão, causou imensa reação a decisão proferida pela Corte no Recurso Extraordinário n.80004, que teria quebrado longa tradição ao decidir: "Embora a Convenção de Genebra que previu uma lei uniforme sobre letras de câmbio e notas promissórias tenha aplicabilidade no direito interno brasileiro, não se sobrepõe elas às leis do País, disso decorrendo a constitucionalidade e conseqüente validade do Decreto-Lei 427/69 que instituiu o registro obrigatório da Nota Promissória em Repartição Fazendária, sob pena de nulidade do título. ${ }^{43}$

Para tratar desse tema, Alexandre Pagliarini lança, inicialmente, a seguinte tese: se uma Constituição nada dispuser a respeito e somar-se a isso o fato de o Estado ser parte celebrante da Convenção de Havana sobre Tratados e da Convenção de Viena sobre Direito dos Tratados, então pode prevalecer a aplicabilidade da norma pactícia internacional prévia, desde que não a fronte a nova Carta. Logo em seguinte, ressalta que "no Brasil, não há nem nunca houve qualquer dispositivo constitucional - direto e expresso - generalizando acerca de hierarquia entre norma pactícia internacional e norma constitucional, nem sobre conflito entre lei interna e tratado internacional". Todavia, destaca que isso não é suficiente para que se conclua que as normas contidas no tratado internacional sobrepõem-se à Lei Magna, mormente porque os tratados estão submetidos ao controle de sua constitucionalidade (art. 102,

\footnotetext{
42 "A controvérsia em torno do tema da recepção dos tratados - e, mais particularmente, da materialização e dos efeitos da integração da norma convencional internacional no direito interno — passou a ganhar corpo na jurisprudência, em razão de deliberações acerca de questões concretas, principalmente a partir da década de 1970, gerando-se, em conseqüência, o fomento da reflexão e do debate doutrinários. (...) A discussão jurisprudencial e doutrinária consistia, basicamente, em dois aspectos: (i) nas décadas de 1970 e 1980, discutiu-se, intensamente, em matéria relacionada a títulos de crédito, a superioridade reconhecida judicialmente para decreto-lei em face de norma anteriormente estipulada em tratado; (ii) após o advento da Constituição de 1988, a polêmica em torno da recepção e integração no direito brasileiro de tratados internacionais de direitos humanos. Embora fossem também pauta de discussão a verificação dos efeitos concretos do Acordo Geral de Tarifas e Comércio - GATT, bem como os acordos binacionais de extradição. (DALLARI, op. cit., p. 53)

${ }^{43}$ BARROSO, op. cit., p. 18.
} 
III, "b", da CF). Deveras, "se o tratado, assim como a lei, está submetido ao controle de constitucionalidade pelo Pretório Excelso, então só se pode inferir que o mesmo ocupa posição inferior à Carta Magna, a não ser nos casos excepcionados pela própria Carta. (...) se é verdade que os tratados podem ser declarados inconstitucionais; e se é também verdadeiro que eles ocupam a mesma hierarquia das leis, pois ambos podem ser declarados contrários à Carta; então os tratados, como as leis ordinárias, devem respeitar a Constituição, sejam eles anteriores ou posteriores ao Texto Magno".

Por fim, conclui Pagliarini que, no Brasil, o tratado é inferior hierarquicamente à Carta Magna, seja ela posterior ou anterior ao texto convencional, devendo, entretanto, o Estado brasileiro ser responsabilizado no plano externo, no caso de optar pela aplicação da Carta em detrimento do tratado e isso corresponder a um ilícito ou contribuir para a produção de uma ilegalidade internacional, o que acarretará ao país o dever de indenizar. $^{44}$

Não obstante haja corrente doutrinária que vê em dois fatores preponderância implícita do tratado sobre a lei brasileira, quais sejam: (i) do tratado, toma conhecimento o Congresso no ato de sua aprovação; (ii) o pacto é ato internacional que obriga o Estado perante co-pactuantes e, sabendo o Congresso que o tratado se encontra em vigor, então não pode editar lei posterior que o contrarie, pois o fato de haver o envolvimento de co-pactuantes limita o poder de criar norma interna contrária ao texto convencional. No entanto "não encontra guarida na Constituição tal posição pelo simples fato da Carta de 1988 — como a anterior — não haver minimamente sugerido que o Poder Legislativo não pode legislar sobre os assuntos previamente dispostos em tratados, e esta verdade se confirma pelo fato de, apesar de ser regra geral a de que o tratado é equivalente em hierarquia à lei, há norma pactícias especiais e isoladas que se sobrepõem às legais domésticas - como por exemplo, os já referidos "tratados tributários" (art. 98, do CTN). Insista-se: a regra geral brasileira é a de que tratado e lei nacional são equivalentes em hierarquia, estando ambos abaixo da Carta; e quando o legislador quis excepcionar, fê-lo expressamente em dispositivos específicos." ${ }^{5}$

Pois bem, nesse tema, o acórdão mais conhecido do STF é aquele

\footnotetext{
${ }_{44}$ Cf. PAGLIARINI, op. cit., p. 157-161.

45 Ibid., p. 163-164. Em outro trecho, ressalta esse autor: "É de se louvar que a doutrina internacionalista propugne pela primazia da norma internacional sobre a nacional: e, realmente, se fosse assim concretamente um mundo de direito internacional compactado uniformemente, seria ótimo, também para o nosso sentir; mas assim não é, porque ainda não se superou o fato de Estados existirem e serem regrados por suas Cartas, e porque assim não quis a Constituição brasileira." (ibid., p. 164)
}

A \& C R. de Dir. Administrativo e Constitucional, Belo Horizonte, ano 5, n. 19, p. 127-159, jan./mar. 2005 
que apreciou o Recurso Extraordinário n. 80004, cujo julgamento teve início em 3 de setembro de 1975, com o voto do Ministro Xavier de Albuquerque, e se estendeu até a sessão de $1^{\circ}$ de junho de 1977, quando votou o Ministro Eloy da Rocha.

De fato, o STF, em 1977, no REX 80004, no qual se apreciou o conflito entre disposições da Lei Uniforme sobre Letras de Câmbio e Notas Promissórias - Tratado celebrado em Genebra - e o Decreto-Lei $\mathrm{n}^{\mathrm{o}}$ $427 / 69$, firmou o entendimento de que o tratado firmado pelo Brasil tem aplicação imediata e direta no direito interno, após a sua ratificação regular pelo Congresso, não sendo necessária a existência de lei que lhe reproduza o conteúdo, bem como reconheceu que o tratado teria equivalência à lei, de modo a revogar lei anterior e ser revogado por lei posterior. ${ }^{46}$

Nesse julgado o Ministro Xavier de Albuquerque discordando de todos os demais, perfilhou o monismo internacionalista, sustentando que, não sendo denunciado tratado ao qual o Brasil estivesse vinculado, seriam manifestamente inconstitucionais as leis que lhe contrariassem, eis que haveria primazia do Direito Internacional Público. ${ }^{47}$

Para Dallari, essa decisão do STF demonstrou a fragilidade da regra brasileira de incorporação de tratados na ordem jurídica nacional, na medida em que admitiu que as regras de tratados poderiam ser afastadas pela mera edição de ato normativo interno. "O que fica dessa decisão, contudo, é a impressão de recuo do Supremo à aceitação da prevalência do direito internacional, tal como esposada por Xavier de Albuquerque, que, significativamente, foi o único que invocou precedentes da Corte naquele sentido, anotados por Haroldo Valladão. (...) Afastando-se da orientação anterior, não atentaram aqueles Ministros para a problemática da responsabilidade do Estado na ordem internacional. E não apenas do Estado como entidade abstrata, mas como pessoa jurídica que atua por indivíduos que o representam perante a comunidade das nações. As decisões judiciais são também atos do Estado que se refletem na ordem internacional e podem acarretar a responsabilidade de que as proferiu, perante a comunidade internacional." ${ }^{48}$

Celso D. de Albuquerque Mello, por sua vez, analisando essa decisão,

\footnotetext{
${ }^{46}$ MAGALHÃES, José Carlos de. O Supremo Tribunal Federal e as Relações entre Direito Interno e Internacional. Boletim Brasileiro de Direito Internacional, n. 61/66, 1975/1979, p. 53.

${ }^{47}$ Cf. FRAGA, op. cit., p. 77.

${ }^{48}$ DALLARI, op. cit., p. 55-56.
}

A \& C R. de Dir. Administrativo e Constitucional, Belo Horizonte, ano 5, n. 19, p. 127-159, jan./mar. 2005 
ressalta que a maioria dos votos sustenta-se em autores antigos e dualistas, como Triepel e que asseverar ser omissa a Constituição importa em atribuir importante papel à jurisprudência, a qual não pode ignorar a tendência atual do direito nesta seara adotando uma concepção de soberania que desapareceu em 1919:

A decisão é das mais funestas, vez que o STF não viu a conseqüência do seu acórdão, que poderá influenciar os juízes nos mais diferentes locais do Brasil. Por outro lado, faltou a ele sensibilidade para o momento atual em que o Brasil intensifica as relações internacionais. Qual o valor de um tratado se um dos contratantes por meio de lei interna pode deixar de aplicá-lo? Se o STF considera que as convenções do direito uniforme estão ultrapassadas cabe ao Executivo denunciá-las no procedimento fixado por elas mesmas, mas não ao STF". Esse julgado foi condenado por Celso D. de Albuquerque Mello: "houve no Brasil um grande retrocesso no RE n. 80004, decidido em 1978, em que o STF decidiu que uma lei revoga tratado anterior. Esta decisão viola também a Convenção de Viena sobre direito dos tratados (1969) que não admite o término do tratado por mudança de direito superveniente..$^{49}$

De outra parte, Jacob Dolinger assevera que o julgado do REX 80004 não importa em mudança de entendimento:

Nossa conclusão é que, excetuadas as hipóteses de tratado-contrato, nada havia na jurisprudência brasileira quanto à prevalência de tratados sobre lei promulgada posteriormente, e, portanto, equivocados todos os ilustres autores acima citados que lamentaram a alegada mudança na posição da Suprema Corte. A posição do STF através dos tempos é de coerência e resume-se em dar o mesmo tratamento a lei e a tratado, sempre prevalecendo o diploma posterior, excepcionados os tratados fiscais e de extradição, que, por sua natureza contratual, exigem denúncia formal para deixarem de ser cumpridos. ${ }^{50}$

\section{A propósito da posição de Dolinger, comenta Luís Roberto Barroso:}

A verdade é que, em exame detido da jurisprudência, Jacob Dolinger constatou que a leitura que a maioria dos autores fazia das decisões do Supremo Tribunal Federal era antes reflexo de sua própria crença no primado do direito internacional do que expressão da realidade dos julgados. Ao contrário do sugerido, a orientação da mais alta corte é a do monismo moderado, em que o tratado se incorpora ao direito interno no mesmo nível hierárquico da lei ordinária, sujeitando-se ao princípio consolidado, em caso de conflito, não se colocando a questão em termos de regra geral e regra particular, prevalece a norma posterior sobre a anterior. ${ }^{51}$

\footnotetext{
${ }^{49}$ MELLO, Celso D.A. Direito Constitucional Internacional. Rio de Janeiro: Renovar, 1994, p. 344.

${ }^{50}$ DOLINGER, Jacob. Direito Internacional Privado: Parte Geral. 2. ed. Rio de Janeiro: Renovar, 1993, p. 102.
} 
A mesma linha de entendimento do REX 80004 foi mantida nas decisões posteriores do Excelso Pretório, consoante fundamentação do Ministro e internacionalista José Francisco Rezek: "O STF deve garantir prevalência à última palavra do Congresso Nacional, expressa no texto doméstico, não obstante isto importasse o reconhecimento da afronta pelo país de um compromisso internacional. Tal seria um fato resultante da culpa dos poderes políticos, a que o Judiciário não teria como dar remédio". ${ }^{52}$

Destarte, em regra geral, os tratados internacionais, no Brasil, possuem o mesmo grau hierárquico das leis internas infraconstitucionais, não podendo, portanto, confrontarem os termos da Carta Magna.

Segundo Pagliarini, para que houvesse superioridade do tratado em relação à lei infraconstitucional, dever-se-iam efetivar uma das seguintes hipóteses: (i) se a Carta de 1988 assim houvesse disposto expressa e diretamente; ou (ii) se a Constituição nada dispusesse a respeito e não houvesse submetido o tratado, ao lado da lei ordinária, ao controle da constitucionalidade. No caso da segunda hipótese (ii), somar-se-ia a ela o fato concreto do Brasil ser parte celebrante da Convenção de Havana sobre Tratados e da Convenção de Viena sobre Direito dos Tratados; então prevaleceria a norma pactícia internacional sobre a lei ordinária pátria, levando-se em conta ainda a posição já comentada na Corte Permanente de Justiça Internacional e da Corte Permanente de Arbitragem de Haia, onde se deliberou que as disposições constitucionais de um Estado não poderiam ser opostas aos direitos internacionais de estrangeiros. (...) De qualquer maneira, a realidade monista moderada que se apresenta no sistema brasileiro, incluindo aí os julgados do STF, não pode afastar a realidade de que, descumprindo o tratado pelo Brasil, por qualquer razão, os prejuízos advindos da inobservância do acordo serem imputados à sua conduta, que deverá ser responsabilizada na mesma medida em que se produzirem as conseqüências do descumprimento do pacto no plano internacional. ${ }^{53}$

Muito embora o entendimento do STF tenha se mantido conforme o julgado do REX 80004, ${ }^{54}$ a posição jurisprudencial predominante de que o tratado equivale à lei ordinária, aplicando-se os critérios da especialidade e cronológico, vem sofrendo vários questionamentos.

\footnotetext{
51 BARROSO, op. cit., p. 19

52 RTJ, 115: 969.

53 PAGLIARINI, op. cit., p. 166-167.

${ }^{54}$ V.G.: Na Extradição n. 662, de 1996, o STF reiterou o reconhecimento da paridade normativa entre leis ordinárias brasileiras e tratados internacionais. "A eventual precedência dos atos internacionais sobre as normas infraconstitucionais de direito interno brasileiro somente ocorrerá (...), não em virtude de uma inexistente primazia hierárquica, mas, sempre, em face da aplicação do critério cronológico (lex posterior derogat priori) ou, quando cabível, do critério da especialidade." (RTJ, 164/421, maio 1998)
} 
Paulo Borba Casella sintetiza a discordância a tal entendimento e ressalta o fato de inexistir uma regra clara no direito brasileiro atinente ao equacionamento da questão da recepção dos tratados:

a validade, interpretação e aplicação dos tratados é matéria em que, igualmente, se ressente o ordenamento jurídico brasileiro da falta de visão institucional, de parâmetros que orientem tanto a atuação dos legisladores internos quanto dos tribunais, porquanto é impensável admitir, como arbitrariamente se pratica entre nós, que a lei interna posterior aleatoriamente revogue ou altere normas decorrentes de tratado internacional. ${ }^{55}$

A equivalência entre tratado e lei e, por conseguinte, a defesa da prevalência da norma mais recente (critério cronológico) ensejam questionamentos concretos, mesmo porque é completamente inadequada a utilização do termo revogar, uma vez que uma lei não revoga um tratado, o qual, por definição, tem natureza contratual e não prescinde do concurso de partes que não se subordinam à vontade soberana de um Estado. Por isso, no STF, adota-se a tese de que a lei posterior ao tratado que lhe seja contrária afasta a efetividade da regra convencional internacional.

Demais disso, há exceções em relação "a essa equiparação entre tratado e lei ordinária para efeito de resolução de conflitos. A primeira dá-se em matéria relativa à tributação, onde o art. 98 do Código Tributário Nacional (Lei n ${ }^{\circ} 5172$, de 25.10.1966), (...), é expresso quanto à prevalência da norma internacional. A segunda exceção refere-se aos casos de extradição, onde se considera que a lei interna (Lei $n^{\circ} 6815$, de 19.08.1980), que é geral, cede vez ao tratado, que é regra especial." ${ }^{56}$

$\mathrm{O}$ art. $5^{\circ}, \S 2^{\circ}$, da CF $/ 88$, conferiu maior complexidade ao debate em torno da integração dos tratados internacionais no direito brasileiro, uma vez que se passou a discutir a extensão da expressão direitos e garantias previstos em tratados internacionais. Interpretando essa regra, Flávia Piovesan defende que os direitos enunciados em tratados internacionais de proteção dos direitos humanos apresentam natureza de norma constitucional, sendo-lhe, portanto, aplicável o regime constitucional atribuído aos demais direitos e garantias fundamentais:

A teoria da paridade entre $o$ tratado internacional e a legislação federal não se aplica aos tratados internacionais de direitos humanos, tendo em vista que a Constituição de 1988 assegura a estes garantia de privilégio hierárquico,

\footnotetext{
55 CASELLA, Paulo Borba. A Integração Econômica e seu Tratado Constitucional. In: Mercosul: Desafios a Vencer. São Paulo: CBRI, 1994, p. 95.

${ }^{56}$ BARROSO, op. cit., p. 19.
}

A \& C R. de Dir. Administrativo e Constitucional, Belo Horizonte, ano 5, n. 19, p. 127-159, jan./mar. 2005 
atribuindo-lhes natureza de norma constitucional. Este tratamento jurídico diferenciado, conferido pelo art. $5^{\circ}$, parágrafo $2^{\circ}$, da carta de 1988 , justifica-se na medida em que os tratados internacionais de direitos humanos apresentam um caráter especial, distinguindo-se dos tratados internacionais comuns. Enquanto estes buscam o equilíbrio e a reciprocidade de relações entre Estados-partes, aqueles transcendem os meros compromissos recíprocos entre os Estados pactuantes. Os tratados de direitos humanos objetivam a salvaguarda dos direitos do ser humano e não das prerrogativas dos Estados. ${ }^{57}$

Embora o $\S 2^{\circ}$, do artigo $5^{\circ}$, represente grande avanço na promoção dos Direitos Humanos, ele peca, segundo Dallari, por apenas fazer referência aos tratados internacionais que preceituam direitos e garantias sem definir precisamente a respectiva posição no quadro das normas jurídicas nacionais, logo não disciplinaria abrangente e diretamente a questão:

O efeito dessa norma constitucional foi gerar ainda maior controvérsia sobre a integração dos tratados na ordem interna, ampliando-se, na doutrina e na jurisprudência (...) o leque de possibilidades advogadas para a disciplina da matéria. ${ }^{58}$

Esse comentário não visa a condenar a garantia conferida aos direitos humanos, bem pelo contrário almeja reforçar o quão lamentável e prejudicial é a ausência de dispositivos expressos e abrangentes sobre o tema da recepção e incorporação dos tratados internacionais ao direito brasileiro. Essa conclusão pode ser confirmada no magistério de Pedro Dallari nos seguintes excertos:

A quase ausência de preceitos escritos sobre o tema da recepção e integração dos tratados internacionais no direito interno é uma marca característica da ordem jurídica brasileira, que, curiosamente, tem a paradoxal propensão à positivação exarcebada. As poucas e esparsas normas formais relacionadas ao tema não permitem que a regra brasileira de regência da matéria detenha os atributos de clareza, precisão, harmonia e exaustão, essenciais à configuração de um verdadeiro sistema, mesmo porque nem sequer são convergentes.

\footnotetext{
${ }^{57}$ PIOVESAN, Flávia. Direitos Humanos e o Direito Constitucional Internacional. São Paulo: Max Limonad, 1996 , p. 94. No mesmo sentido, assevera Pedro Dallari: "se a Constituição de 1988, através da regra do $\S 2^{\circ}$ do art. $5^{\circ}$, faz ressaltar os tratados internacionais que cuidam dos Direitos Humanos, destacando-os dos demais, não seria para conferir àqueles tratamento idêntico ao que estes já recebem no âmbito do sistema jurídico brasileiro. Parece lógico, portanto, nos marcos de uma hermenêutica clássica, o entendimento de que, se a Constituição distinguiu os tratados de Direitos Humanos, o fez para assegurarIhes uma condição mais relevante no quadro da hierarquia das normas jurídicas vigentes no Brasil do que aquela reconhecida para o restante das normas convencionais internacionais, sendo plenamente defensável, portanto, a tese da equiparação constitucional dos primeiros.(...) O Direito Internacional dos Direitos Humanos não pode ser enfocado como mera especialidade do Direito Internacional Público, pois sua base de legitimação supera em muito a natureza marcadamente contratual que, como regra geral, caracteriza o Direito das Gentes." (DALLARI, op. cit., p. 61)

58 Ibid., p. 48
}

A \& C R. de Dir. Administrativo e Constitucional, Belo Horizonte, ano 5, n. 19, p. 127-159, jan./mar. 2005 
O próprio entendimento jurisprudencial reveste-se de contradições e ambigüidades, e a posição adotada pelo Supremo Tribunal Federal, de simples equiparação dos tratados às leis federais, não obteve o pleno acatamento da doutrina e é freqüentemente contestada ou, de maneira mais sutil, contornada por decisões judiciais em variadas instâncias inferiores. ${ }^{59}$

a despeito de volumosa produção doutrinária, não foi possível construir, nos anos recentes, um quadro analítico capaz de propiciar uma - ou mesmo mais de uma - formulação que dê conta de disciplinar a recepção e integração dos tratados ao direito brasileiro e dê respostas às múltiplas questões a ele adstritas. Da assistematicidade do direito positivo deriva claramente a dificuldade de se resolver, pela via da hermenêutica, matéria por demais complexa, o que reforça uma premissa básica deste estudo, que é a imprescindibilidade de um regramento constitucional expressamente voltado ao balizamento da incorporação das normas de Direito Internacional Público na ordem jurídica nacional. ${ }^{60}$

\section{Fragilidade da regra brasileira de recepção de tratados internacionais e integração econômica}

Os problemas ensejados pela ausência de normatização relativa à integração dos tratados internacionais no direito brasileiro são gradativamente mais graves em virtude do cenário hodierno de propensão acentuada à integração entre os Estados.

Desde logo, ressalte-se que "o Direito Internacional Público não se encorpa necessariamente às custas do enfraquecimento do poder normativo do Estado, mas sim à medida que este, no exercício da soberania que lhe é inerente, assume compromissos e adquire responsabilidade na ordem internacional...”61

Neste aspecto, José Eduardo Faria defende que o papel do Estado é ainda importante e indispensável, mesmo porque o multilateralismo e a regionalização são possibilidades de processos de integração internacional promovidos com forte predominância das instituições do Estado. ${ }^{62}$

De outra parte, não se olvide que "a integração internacional (e, em especial, latino-americana), cuja culminância geralmente importa no fortalecimento de instituições supranacionais, é verdadeira condição de sobrevivência da Soberania, frente a um poder econômico cada vez mais forte, ilimitado e internacionalizado, que caracteriza a face nefasta do atual processo de globalização, principalmente para os povos de países

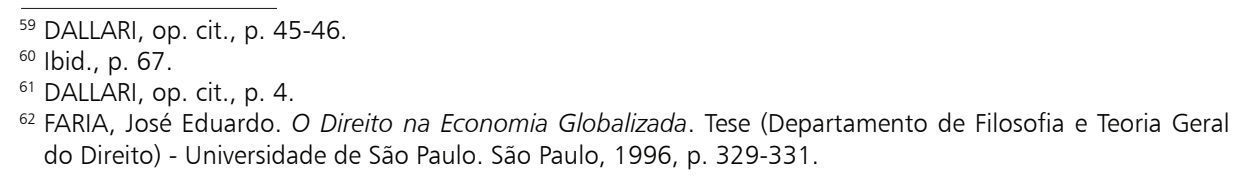


em desenvolvimento, ou 'emergentes', como os latino-americanos, que, em contrapartida, nada 'concedem' ou abdicam da sua própria Soberania, pois contratam, livre e justamente, a proteção e a salvaguarda desta, através de organismos internacionais de integração, dotados ou não de instituições supranacionais." ${ }^{3}$

No bojo da Constituição Brasileira, utilizando-se o instrumento interpretativo consubstanciado no princípio da unidade da constituição - segundo o qual o direito constitucional deve ser interpretado de forma a evitar contradições (antinomias, antagonismos) entre suas normas e, sobretudo, entre seus princípios - e o seu corolário lógico o princípio da concordância prática, ${ }^{64}$ é possível ressaltar que a Constituição, ao enquadrar tanto a soberania (art. $1^{\circ}$, I, da CF) quanto a busca pela integração econômica latino-americana (art. $4^{\circ}$, parágrafo único, da CF) como princípios fundamentais da República Federativa do Brasil, tratou de evitar qualquer possibilidade de antinomia entre os Princípios da Soberania e de Integração Latino-americana, incumbindo o intérprete da determinação de entendimento que harmonize e garanta eficácia a ambas as normas fundamentais.

Afastada qualquer antinomia entre tratado internacional/integração e soberania, resta destacar que o Estado Brasileiro vivencia um verdadeiro paradoxo, uma vez que ao mesmo tempo em que intensifica seus vínculos com a estrutura normativa do Direito Internacional Público, de outro lado não assume claramente o compromisso com a plena incorporação das regras desse sistema supranacional ao ordenamento jurídico interno. ${ }^{65}$

Ao verificar não só esse paradoxo, mas também que é praticamente inequívoca a fragilidade da regra brasileira de recepção e integração dos tratados internacionais no direito interno do País, conclui Pedro Dallari que seria perfeitamente cabível promover uma proposta de sistema de regras jurídicas para disciplinar de forma clara e abrangente o tema. Para tanto, ele atenta, inicialmente, a dois aspectos, quais sejam: de um lado a qualidade do compromisso formal perante a comunidade internacional consubstanciada na norma convencional e, de outro, a necessidade imperiosa de respeitar os parâmetros sistêmicos do ordenamento jurídico do Estado. ${ }^{66}$

${ }^{63}$ STRAUS, op. cit., p. XV.

${ }^{64}$ Cfr. CANOTILHO, J.J. Gomes. Direito Constitucional. 5. ed. Coimbra: Almedina, 1991, p. 232.

${ }^{65}$ Cf. DALLARI, op. cit., p. 80.

A \& C R. de Dir. Administrativo e Constitucional, Belo Horizonte, ano 5, n. 19, p. 127-159, jan./mar. 2005 
Essa necessidade de assegurar a real observância, no direito interno, das regras oriundas de tratados internacionais não deriva de eventual e autoconferida supremacia do Direito Internacional Público, bem pelo contrário é resultante lógica do pressuposto da efetividade das decisões adotadas soberanamente - e nos termos da correspondente ordem jurídica - pelo Estado e por suas instituições.

O sistema forjado por Dallari inspira-se nos tratamentos conferidos ao assunto seja pelas Constituições ibéricas da década de 1970, produzidas no bojo do processo de redemocratização e que propiciaram não só o êxito desse processo, mas também viabilizaram a integração daqueles Estados à comunidade européia; seja pelas reformas produzidas nas Constituições européias, na década de 90, para compatibilizá-las às diretivas presentes no Tratado sobre a União Européia (Tratado de Maastricht), que intensificou e muito a integração européia; seja as alterações promovidas na Constituição Argentina em 1994 para ajustar suas instituições ao advento do Mercosul.

Pois bem, Dallari fixa pressupostos de ordem material e procedimental à sua proposta para sanar a fragilidade. Na medida em que essa questão deve ser tratada pelo direito interno do Estado e, por força de sua relevância, por normas de jaez constitucional, o procedimento adequado ao estabelecimento de um novo sistema integrador dos tratados é a emenda constitucional, até porque se fará necessária a alteração dos quorum do processo legislativo, bem como a modificação das atribuições do Presidente da República. ${ }^{67}$ A par desse requisito de ordem procedimental, há que se estabelecer dois pressupostos de jaez substancial: (i) "o reconhecimento da integração internacional dos Estados, inclusive sob o aspecto da consolidação de um conjunto expressivo de normas de Direito Internacional Público, como um processo irreversível e de intensidade crescente"; (ii) "a necessidade de que esse processo de integração internacional desenvolva-se com fundamento na vontade soberana do povo de cada Estado, manifestada por via de mecanismos democráticos institucionalmente consagrados, a fim de que possa redundar na efetiva promoção dos Direitos Humanos e na elevação da qualidade de vida da população do planeta". ${ }^{68}$

Por conta desses dois pressupostos, faz-se mister, no direito brasileiro,

\footnotetext{
${ }^{66}$ DALLARI, op. cit., p. 123-124.

${ }^{67}$ DALLARI, op. cit., p. 125.
}

A \& C R. de Dir. Administrativo e Constitucional, Belo Horizonte, ano 5, n. 19, p. 127-159, jan./mar. 2005 
que se confira ao tratado, ao contrário do que sucede hodiernamente, maior relevância no âmbito das normas vigentes no território nacional e plena efetividade de suas disposições; bem como a vinculação do Estado ao tratado deverá arrimar-se num maior grau de adesão social que hoje fica restringido à deliberação parlamentar (democracia representativa) ${ }^{69}$

De tal sorte, é possível moldar a proposta de emenda com as seguintes características: (i) previsão expressa da incorporação do tratado internacional ao direito interno; (ii) reconhecimento de status hierárquico superior ao tratado em relação às leis complementares e ordinárias; (iii) possibilidade de apreciação da constitucionalidade de tratado pelo STF previamente à deliberação do Congresso Nacional; (iv) previsão da exigência de promulgação de emenda constitucional aprovada pelo Congresso Nacional previamente à aprovação legislativa de tratado nos casos em que essa condição seja assinalada pelo STF; (v) fixação de quorum qualificado de três quintos à aprovação de tratado pelo Congresso Nacional; (vi) exigência de aprovação prévia do Congresso para efetivação de denúncia a tratado; (vii) reconhecimento da vigência no Brasil das normas emanadas de organizações internacionais de que o País faça parte, desde que expressamente previsto nos respectivos tratados constitutivos. ${ }^{70}$

Como se vê, na proposta de Pedro Dallari, fixa-se a superioridade das normas convencionais diante das leis ordinárias e complementares, ao passo que, para as decisões de organizações internacionais, mesmo aquelas de caráter comunitário ou de integração, a questão deve ficar remetida aos respectivos tratados constitutivos, porque, diferentemente do que se dá com estes tratados, cuja literalidade das disposições normativas é examinada pelo legislador brasileiro previamente ao ato de ratificação ou adesão, tal não ocorre com as decisões de organizações internacionais.

Assim, a integração das decisões emanadas das organizações internacionais de qualquer natureza dependerá das condições que estiverem assinaladas à recepção no texto do tratado constitutivo do ente supranacional, tratado esse que obrigatoriamente deverá ser submetido à aprovação do Congresso, o qual poderá fazer, se desejar, uso do instrumento da reserva.

A previsão da atribuição do Congresso de aprovar previamente a denúncia de tratado internacional visa a estabelecer compatibilidade entre a norma que confere a competência ao Congresso em matéria de vinculação a tratados e aquela que trata das atribuições do Presidente. Mesmo porque

68 Ibid., p. 126.

${ }^{69} \mathrm{Cf}$. DALLARI, op. cit., p. 126.

70 Ibid., p. 126-127.

A \& C R. de Dir. Administrativo e Constitucional, Belo Horizonte, ano 5, n. 19, p. 127-159, jan./mar. 2005 
seria contraditório conferir maior efetividade aos tratados se a possibilidade de cessação de seus efeitos — denúncia - ficasse adstrita ao simples talante do Chefe do Poder Executivo Federal. ${ }^{71}$

Já prevendo possível crítica à sua proposta, no que concerne à inexistência de consulta popular seja para celebração, seja para a denúncia de tratado internacional, Pedro Dallari ressalta que não se trata de "repúdio a mecanismos que, indiscutivelmente, constituem expedientes relevantes infelizmente pouco adotados no Brasil — para a melhor aferição da vontade coletiva. Ocorre, todavia, que a atual Constituição brasileira já contempla de maneira genérica tal possibilidade, quando preceitua, no art. 49, XV, competir exclusivamente ao Congresso Nacional 'autorizar referendo e convocar plebiscito'. Portanto, nada impede que o Congresso Nacional, se julgar necessário, aprove decreto legislativo com tal finalidade. Não se trata, assim, de substituir os procedimentos e suprir as competências arroladas constitucionalmente para os Poderes Legislativo e Executivo da União, mas sim de adendar uma nova etapa, que, para o caso específico indicado pelo Congresso Nacional, seria essencial à constituição do vínculo obrigacional internacional. É certo que a tradição brasileira não faz prever a disseminação dessa prática. Porém, o avanço na formalização da participação do País em sistemas de integração regional — com o incremento do Mercosul e a perspectiva de constituição da Área de Livre Comércio das Américas (ALCA) - pode perfeitamente ensejar a oportunidade da utilização do mecanismo de consulta popular para a validação — ou não — dessas iniciativas institucionais de impacto extremamente significativo."72

Apesar dessa resposta/justificativa prévia de Pedro Dallari, deve-se ressaltar ser imprescindível constar, na proposta de emenda, mecanismos de democracia participativa, uma vez que não é suficiente para atender os anseios da soberania popular uma democracia meramente representativa, até porque em diversos outros temas têm se contemplado a participação direta e não por via de representantes, ex: Audiência popular, orçamento participativo etc.

Pois bem, a fixação de quorum qualificado à aprovação do decreto legislativo do ato de ratificação ou de adesão a tratado internacional constitui o ponto central do sistema proposto por Dallari, na medida em que estreita os laços entre o patamar de relevância e o grau de respaldo social

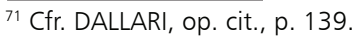

72 DALLARI, op. cit., p. 140.
}

A \& C R. de Dir. Administrativo e Constitucional, Belo Horizonte, ano 5, n. 19, p. 127-159, jan./mar. 2005 
imprescindível à aprovação respectiva, que, na democracia representativa, é mensurado basicamente pela manifestação da representação popular reunida no parlamento. Esse quorum qualificado também garante a pretensão de conferir às normas do tratado superioridade em relação às leis infraconstitucionais. ${ }^{73}$

Como se vê, fixa-se aos tratados um procedimento intermediário entre as emendas e as leis infraconstitucionais e, por conseguinte, uma posição hierárquica também intermediária.

O estabelecimento de um exame prévio da constitucionalidade do tratado pelo STF inspira-se no sistema francês e se insere no bojo do movimento que busca conferir ao STF a natureza de corte constitucional, isto é, de guardião da ordem constitucional, sendo, portanto, adequado que o STF tivesse a responsabilidade direta pelo monitoramento da vinculação do Brasil à crescente estrutura normativa do Direito Internacional Público.

Por fim, convém restar bem claro que a urgência no encaminhamento de proposta de emenda dessa natureza justifica-se, desde logo, pela "percepção da inadequação dos mecanismos atuais que regulam a validade interna dos tratados em face do incremento do processo de inserção do Brasil na comunidade internacional, hoje inevitavelmente vinculada a uma pauta temática comum que arrola, entre outros desafios, a proteção universal dos Direitos Humanos, a efetividade da democracia, a adoção de políticas planetárias de promoção do equilíbrio ambiental e a pactuação de normas regulatórias do fluxo transnacional de bens, notadamente de capitais financeiros. O fim da ditadura militar e a redemocratização do País, em um momento inicial, e, já na década de 1990, a perspectiva de viabilização de políticas de desenvolvimento lastreadas no fomento da integração internacional comercial e financeira contribuíram para esmaecer a natureza marcadamente autárquica de ordem política, econômica e social - e de seus efeitos no universo do direito - até então reinante no território brasileiro" 74

Consentânea é a metáfora criada por Pagliarini: ${ }^{75}$

"se correr o bicho pega" significa prudência, pois, ao se integrar na comunidade internacional, um Estado não pode relegar a posto sem relevo documento de tamanha importância, como é a Constituição. Por outro lado, "se ficar o bicho

\footnotetext{
${ }^{73}$ DALLARI, op. cit., p. 141

74 Ibid., p. 152.
}

A \& C R. de Dir. Administrativo e Constitucional, Belo Horizonte, ano 5, n. 19, p. 127-159, jan./mar. 2005 
come" conota a verdade que não pode um Estado se manter isolado da vida além fronteiras que a pós-modernidade impõe. (...) deve-se preservar a Lei Magna, adaptando- $a$ à entrada do Estado Nacional na comunidade internacional, reformulando-se, para isso, o velho conceito de soberania. Esta é a globalização jurídica que, para nós, equivale a integrar-se sem entregar-se a ponto de perder a identidade. Desta forma, voltando-se à frase que inaugurou a presente obra, a mesma merece reforma, para sua melhor compreensão: "o bicho não pega quem não sai correndo nem quem não fica parado, pois caminhando não se o assusta".

\section{Conclusão}

1 Muito embora, desde o período antigo, os Estados visem, através de tratados e pactos, a estabelecer e manter a paz, todavia, somente em meados do século XIX, o fenômeno convencional foi impulsionado e sofreu uma transformação considerável, em virtude da crescente solidariedade entre os diversos elementos da sociedade internacional.

2 Os tratados multilaterais e as organizações internacionais devem ser considerados as principais causas da evolução do fenômeno convencional e constituem resultado da crescente solidariedade internacional.

3 Com a importância crescente do tratado no rol das fontes do Direito Internacional Público, o conflito eventual entre este e o direito interno passou a ser enfocado primordialmente sob a ótica da integração do ato convencional à ordem jurídica nacional.

4 Há diferentes modelos constitucionais de sistemas de integração dos Tratados ao Direito Interno, os quais podem ser enquadrados em quatro espécies: (i) adoção global da regra do Direito Internacional pelo direito interno, sem, todavia, instituir a primazia de uma sobre a outra; (ii) adoção global com primazia do direito internacional; (iii) sistema de incorporação obrigatória, mas não automática; (iv) aqueles cuja Constituição, embora submeta o Estado ao direito internacional, não trata da integração deste no direito interno.

5 A diferença existente entre esses modelos, mesmo com a adaptação aos tempos hodiernos, denota a dificuldade que efetivamente é imposta à plena observância dos tratados no âmbito do sistema jurídico de cada Estado, não obstante a crescente propensão à pactuação na esfera do Direito Internacional Público.

6 O direito interno do Estado-parte não constitui pretexto, tampouco justificativa plausível, no âmbito do Direito Internacional Público, ao descumprimento de um tratado internacional, cuja aquiescência de 75 PAGLIARINI, op. cit., s/n Introdução. 
tal Estado ao pacto tenha sido livremente externada como inequívoca manifestação de vontade. Logo, deve o Estado que não pretende cumprir determinada norma internacional recorrer à renúncia desse tratado, não lhe sendo possível, para tanto, esteiar-se no direito interno.

7 A relação e equacionamento entre Direito Internacional Público e o direito interno foram analisadas por duas clássicas concepções: monista e dualista. Isto é, ou os dois ordenamentos jurídicos são independentes, distintos, separados e impenetráveis (dualismo) ou derivam um do outro (monismo).

8 Hodiernamente, defende-se um monismo de compatibilização que importa na integração das normas de Direito Internacional Público com o direito interno do Estado, bem como a substituição da idéia de primazia de uma ou de outra ordem por uma perspectiva de articulação entre ambas, superando-se, assim, a polarização entre monismo internacionalista e monismo nacionalista.

9 Em que pese não haja clareza, precisão, harmonia e exaustão na regra que trata no direito brasileiro da recepção e integração dos tratados internacionais, é possível sintetizar suas características: (i) a vinculação do Estado brasileiro a um tratado internacional dá-se mediante a sua ratificação ou adesão, a qual resulta de ato do Presidente da República, que deve, por sua vez, ser precedido, em regra, pela aprovação, pelo Congresso Nacional, do texto convencionado; (ii) o tratado passa a produzir efeitos internamente na data para sua entrada em vigência prevista no decreto de promulgação do Presidente da República e após a publicação desse mesmo decreto; (iii) estando em vigor no território nacional, o tratado resta automaticamente incorporado ao direito brasileiro, sem a necessidade de edição de lei interna que lhe reproduza o teor; (iv) conforme a jurisprudência dominante, o tratado, no plano da hierarquia normativa, equivale à lei interna, aplicandose os critérios cronológico e da especialidade, bem como não há distinção hierárquica entre diferentes tipos de tratados; (v) o tratado pode ser denunciado pelo Presidente da República, não sendo necessária a autorização prévia do Congresso Nacional; (vi) não há, no direito interno, dispositivo que trate da recepção das decisões emanadas das organizações internacionais.

10 Quanto à hierarquia normativa, como o tratado, assim como a lei, está submetido ao controle de constitucionalidade, infere-se que ele ocupa posição inferior à Carta Magna. Deveras, os tratados, como as 
leis ordinárias, devem respeitar a Constituição, sejam eles anteriores ou posteriores ao Texto Magno

11 Em regra geral, os tratados internacionais, no Brasil, possuem o mesmo grau hierárquico das leis internas infraconstitucionais, não podendo, portanto, confrontarem os termos da Carta Magna. Há, no entanto, exceções: (i) Tratados tributários, por força do art. 98 do CTN e pelo fato de ser tal código uma lei complementar à Carta, afastam a aplicabilidade de leis internas que os contradigam, sejam essas leis anteriores ou posteriores ao texto pactício; (ii) Tratados de direitos humanos, tendo em vista a norma constante no parágrafo $2^{\circ}$ do art. $5^{\circ}$ da Carta brasileira, têm estatura constitucional, pois assim quis a própria Lei Maior.

12 Os problemas ensejados pela ausência de normatização relativa à integração dos tratados internacionais no direito brasileiro são gradativamente mais graves em virtude do cenário hodierno de propensão acentuada à integração entre os Estados.

13 Afastada qualquer antinomia entre tratado internacional/ integração e soberania, resta destacar que o Estado Brasileiro vivencia um verdadeiro paradoxo, uma vez que ao mesmo tempo em que intensifica seus vínculos com a estrutura normativa do Direito Internacional Público, de outro lado não assume claramente o compromisso com a plena incorporação das regras desse sistema supranacional ao ordenamento jurídico interno.

14 Nessa conjuntura, urge erigir novo sistema integrador dos tratados, cujo procedimento adequado ao estabelecimento é a emenda constitucional, até porque se fará necessária a alteração dos quorum do processo legislativo, bem como a modificação das atribuições do Presidente da República.

15 Essa proposta de emenda deverá contemplar dispositivos que confiram não só maior relevância no âmbito das normas vigentes no território nacional e plena efetividade de suas disposições; bem como a vinculação do Estado ao tratado deverá arrimar-se num maior grau de adesão social que hoje fica restringido à deliberação parlamentar (democracia representativa).

\section{Bibliografia}

ACCIOLY, Hildebrando. Manual de Direito Internacional Público. 12. ed. São Paulo: Saraiva, 1996.

BARROSO, Luís Roberto. Interpretação e Aplicação da Constituição. 4. ed. São Paulo: Saraiva, 2001.

A \& C R. de Dir. Administrativo e Constitucional, Belo Horizonte, ano 5, n. 19, p. 127-159, jan./mar. 2005 
CANOTILHO, J.J. Gomes. Direito Constitucional. 5. ed. Coimbra: Almedina, 1991.

CASELLA, Paulo Borba. A Integração Econômica e seu Tratado Constitucional. In: Mercosul: Desafios a Vencer. São Paulo: CBRI, 1994.

CASSESE, Antonio. Modern Constitutions and International Law. Recueil des Cours de l'Académie de Droit Internacional de la Haye, Tomo III 192. Dordrecht (Holanda): Martinus Nijhoff Publishrs, 1986.

DALLARI, Pedro B. A. Constituição e Tratados Internacionais. São Paulo: Saraiva, 2003.

DOLINGER, Jacob. Direito Internacional Privado: Parte Geral. 2. ed. Rio de Janeiro: Renovar, 1993.

FARIA, José Eduardo. O Direito na Economia Globalizada. Tese (Concurso para professortitular) - Departamento de Filosofia e Teoria Geral do Direito da Universidade de São Paulo. São Paulo, 1996.

FRAGA, Mirtô. O Conflito entre Tratado Internacional e Norma de Direito Interno: Estudo Analítico da Situação do Tratado na Ordem Jurídica Brasileira. Rio de Janeiro: Forense, 1997.

KELSEN, Hans. Les Rapports de Système entre le Droit Interne et el Droit International Public. Recuil des Cours de l'Ácademie de Droit International de la Haye, 1926, IV. Paris (França): Librairie Hachette, 1927.

MAGALHÃES, José Carlos de. O Supremo Tribunal Federal e as Relações entre Direito Interno e Internacional. Boletim Brasileiro de Direito Internacional, n.61/66, 1975/1979.

MEDEIROS, Antonio Paulo Cachapuz de. O Poder de Celebrar Tratados - Competência dos Poderes Constituídos para a Celebração de Tratados, à Luz do Direito Internacional, do Direito Comparado e do Direito Constitucional Brasileiro. Porto Alegre: Sérgio A. Fabris, 1995.

MELLO, Celso D.A. Direito Constitucional Internacional. Rio de Janeiro: Renovar, 1994.

PAGLIARINI, Alexandre Coutinho. Constituição e Direito Internacional: Cedências Possíveis no Brasil e no Mundo Globalizado. Rio de Janeiro: Forense, 2003.

PIOVESAN, Flávia. Direitos Humanos e o Direito Constitucional Internacional. São Paulo: Max Limonad, 1996.

RANGEL. Vicente Marotta. Os Conflitos entre Direito Interno e os Tratados Internacionais. Revista da Faculdade de Direito da Universidade de São Paulo, São Paulo, ano 62, fasc.2, 1967.

REUTER, Paul. Introdución al Derecho de los Tratados. Ed. Revisada por Peter Haggenmacher. México: Fondo de Cultura Económica, 1999.

ROUSSEAU, Charles. Derecho Internacional Publico. Barcelona: Ariel, 1996.

STRAUS, Flávio Augusto Saraiva. Soberania e Integração Latino-Americana - Uma Perspectiva Constitucional do Mercosul. Rio de Janeiro: Forense, 2002.

TRINDADE, Antônio Cançado. O Direito Internacional em um Mundo em Transformação. Rio de Janeiro: Renovar, 2002.

A \& C R. de Dir. Administrativo e Constitucional, Belo Horizonte, ano 5, n. 19, p. 127-159, jan./mar. 2005 
Informação bibliográfica deste texto, conforme a NBR 6023:2002 da Associação Brasileira de Normas Técnicas (ABNT):

RECK, Melina Breckenfeld. Fenômeno convencional, sistema brasileiro de recepção de tratados internacionais e a necessidade hodierna de integração econômica. $A{ }^{E}{ }^{2} C$ Revista de Direito Administrativo e Constitucional, Belo Horizonte, ano 5, n. 19, p. 127-159, jan./mar. 2005. 